\title{
FLUOROANHYDRITE COMPOSITIONS PLASTICIZED BY POLYCARBOXYLATE ESTERS
}

\author{
Daria A. KALABINA ${ }^{1 *}$, Grigoriy I. YAKOVLEV ${ }^{1}{ }^{1}$, Zdenek DUFEK ${ }^{2}$, \\ Grigoriy N. PERVUSHIN ${ }^{1}$, Kirill A. BAZHENOV ${ }^{1}$, \\ Viktoriya V. TROSHKOVA ${ }^{1}$ \\ ${ }^{1}$ Izhevsk State Technical University named after M.T. Kalashnikov, Studencheskaya str. 7, \\ 426069 Izhevsk, Russian Federation \\ ${ }^{2}$ Brno Technical University, Vevery st. 95, 60200 Brno, Czech Republic
}

Received 13 November 2019; accepted 23 December 2019

\begin{abstract}
The influence of a plasticizer based on polycarboxylate esters on the properties of a high-strength fluoroanhydrite composition and a lightweight composition with expanded perlite sand is investigated. It was shown that the addition of $2 \%$ polycarboxylate esters on water base to compositions has increased compressive strength and a flexural strength up to $46 \%$ and $20 \%$ respectively compare to composite without any additives. Due to the structure's compaction of the compositions, water absorption decreased and the water resistance of the material increased. Microstructural analysis of the compositions confirmed the improvement of physical and mechanical characteristics by changing the morphology of crystallohydrate formations, increasing the contact area between new formations and modifying the structure by carbon nanotubes. The developed mixtures are supposed to be apply for self-leveling fluid mixtures for floors with reduced thermal conductivity.
\end{abstract}

Keywords: fluoroanhydrite, perlite, polycarboxylate, plasticizer, nanotubes, microstructure.

\section{Introduction}

In the context of actively growing volumes of new construction and reconstruction of existing facilities, there is a high demand for dry building mixes, among which flooring levelers and self-leveling compositions are in demand. Self-leveling screeds are used to level the surface, give it stiffness, form a slope, and provide a certain level of heat absorption of the floor. Dry mixes used as floor levelers involve the use of Portland cement. However, gypsum and anhydrite compounds are widely used in construction due to a number of advantages: environmental friendliness, regulation of humidity conditions, sound and heat insulating ability, increased fire safety (Goncharov et al., 2016).

There is a development of self-leveling mixtures based on phosphogypsum with the addition of calcium sulfoaluminate cement and granulated blast furnace slag, which allowed to obtain strength at the age of 1 day: compressive strength $6 \mathrm{MPa}$, tensile bending strength $2.5 \mathrm{MPa}$ (Wang \& Jia, 2019).

In Dolgorev et al., (2008), a light heat and sound insulating dry mixture is proposed, which includes gypsum binder, polystyrene foam granules, modifiers, and adjusting additives. The mixture characteristics are the following: density $610 \mathrm{~kg} /$ cubic meter, thermal conductivity $0.11 \mathrm{~W} / \mathrm{m}^{\circ} \mathrm{C}$, water resistance 0.87 , compressive strength $1.5 \mathrm{MPa}$ (after 2 days). A high-strength flooring (suggested as a top layer over a heat-insulating one) based on gypsum binder, quartz sand, and additives of the following characteristics has been developed: density $2100 \mathrm{~kg} /$ cubic meter, thermal conductivity $0.72 \mathrm{~W} / \mathrm{m}^{\circ} \mathrm{C}$, water resistance 0.98 , and compressive strength $25 \mathrm{MPa}$ (after 6 days). The drying and hardening time of both compositions is 3 days.

A method for producing an anhydrite binder from technogenic anhydrite of the Polevsky cryolite plant has been patented (Pureskina et al., 2010). The resulting binder has a compressive strength of $27 \mathrm{MPa}$ and the following setting time: start at 10 minutes and end at 20 minutes. High strength indicators were achieved due to using potassium sulfate as a hardening accelerator in an amount of $1 \%$ by the weight of anhydrite and polycarboxylate as a superplasticizer in an amount of $0.4 \%$.

${ }^{\star}$ Corresponding author. E-mail: 4450539@gmail.com 
Currently, solutions of polycarboxylate esters are widely used to improve the technological properties of concrete, mixes, and gypsum products (Hampel et al., 2013), as well as ceramics: cement and gypsum plaster mixes, floor screeds, wall blocks, cast architectural details, ceramic bricks.

Polycarboxylate superplasticizer is considered the most effective dispersant of cement-based materials and also demonstrates excellent ability to disperse gypsum particles (Tan et al., 2018; Neuville et al., 2012; Guan et al., 2010). Adding an aqueous solution of polycarboxylate esters increases the strength (Sakthieswaran \& Sophia, 2018; Pan \& Wang, 2011), reduces water demand (Martin, 2015) and increases the consistency of mixtures (Müller \& Hampel, 2018). High workability of mixtures modified with polycarboxylate esters can significantly expand their field of application and makes them suitable for self-leveling floor screeds.

The aim of this study was to increase the physico-mechanical characteristics of fluoroanhydrite compositions to expand their field of use. In the course of the work, the effect of a plasticizer based on an aqueous solution of polycarboxylate esters on the properties of high-strength and lightweight expanded pearlite sand compositions based on technogenic anhydrite (Yakovlev et al., 2019a), namely, fluoroanhydrite, a waste product of hydrofluoric acid, was studied.

The use of industrial waste is known to be one of the primary tasks of building materials science; therefore, the development of fluoroanhydrite-based compositions seems relevant from the point of view of reducing the cost of products and environmental load in places of waste accumulation (Fedorchuk, 2013).

\section{Materials and methods}

For producing a high-strength binder, powdered fluoroanhydrite was used, which is a waste product of hydrofluoric acid produced by "HaloPolymer," corresponding to TS 5744-132-05807960-98.

The chemical composition of fluoroanhydrite is given in Table 1.

Expanded perlite sand (GOST 10832-2009) with a bulk density of $98.9 \mathrm{~kg} / \mathrm{m}^{3}$ was used in the experiment. The chemical composition of expanded perlite sand is given in Table 2.

Table 1. Chemical composition of fluoroanhydrite, \%

\begin{tabular}{|c|c|c|c|c|c|}
\hline $\mathrm{CaO}$ & $\mathrm{SO}_{3}$ & $\mathrm{CaF}_{2}$ & $\mathrm{SiO}_{2}$ & $\mathrm{Al}_{2} \mathrm{O}_{3}$ & $\mathrm{Fe}_{2} \mathrm{O}_{3}$ \\
\hline $35.0-36.5$ & $\begin{array}{c}\text { not less } \\
\text { than 45 }\end{array}$ & $2.2-5$ & $2.6-3.4$ & $0.5-0.7$ & $0.2-0.95$ \\
\hline
\end{tabular}

Table 2. Chemical composition of expanded perlite sand, \%

\begin{tabular}{|c|c|c|c|c|}
\hline $\mathrm{SiO}_{2}$ & $\mathrm{Al}_{2} \mathrm{O}_{3}$ & $\mathrm{~K}_{2} \mathrm{O}$ & $\mathrm{TiO}_{2}$ & $\mathrm{CaO}+\mathrm{Mg}_{2} \mathrm{O}+\mathrm{Fe}_{2} \mathrm{O}_{3}$ \\
\hline 73 & 15 & 4.7 & 5.0 & 2.3 \\
\hline
\end{tabular}

Dispersion analysis (Yakovlev et al., 2019a) showed that the average particle size of the expanded perlite sand is $65 \mu \mathrm{m}$, up to $72 \%$ of the particles of the expanded sand have sizes up to $100 \mu \mathrm{m}$. The average particle diameter is $10.5 \mu \mathrm{m}$. It is necessary to note the presence of a nanodispersed component in the composition of fluoroanhydrite with the average particle size of $140 \mathrm{~nm}$.

The experiment used a superplasticizer DC-5, which is an aqueous solution of polycarboxylate esters modified with multi-walled carbon nanotubes (TS 2493-00168708012-2014).

\section{Analysis of physical and mechanical characteristics of compositions}

To determine the physico-mechanical parameters, the compositions were prepared in the following order: fluoroanhydrite was tempered with an aqueous solution containing 2-3\% activator of hydration of sodium phosphate (Yakovlev et al., 2018) and 2\% DC-5 superplasticizer. In lightweight formulations, expanded perlite was added into the finished fluoroanhydrite dough to provide better adhesion of the aggregate surface to the binder matrix (Yakovlev et al., 2019b).

The composition of compounds:

1 - control - fluoroanhydrite tempered with a $3 \%$ aqueous solution of sodium phosphate;

2 - fluoroanhydrite tempered with an aqueous solution containing $3 \%$ of sodium phosphate and $2 \%$ of DC-5 superplasticizer;

3 - fluoroanhydrite tempered with a $3 \%$ aqueous solution of sodium phosphate, $50 \%$ of expanded perlite sand added (by dry volume);

4 - fluoroanhydrite tempered with an aqueous solution containing $3 \%$ of sodium phosphate and $2 \%$ of DC-5 superplasticizer, $50 \%$ of expanded perlite sand added (by dry volume).

To determine the strength characteristics of the studied compositions, beam samples with dimensions of $40 \times 40 \times 160 \mathrm{~mm}$ were made, which hardened for the first 7 days in a humid environment and then under normal conditions until the age of 28 days. In order to ensure the reliability of the test results, for determining the water resistance of the material the samples remained in a humid environment up to the age of 28 days.

The test results are shown in Table 3.

Thus, it can be concluded that adding the plasticizer into the composition made it possible to increase the tensile bending strength of the samples by $20 \%$ and compressive strength by $30-46 \%$. In addition, due to compaction of the compositions, the indicators of water absorption and water resistance significantly improved.

The effect of the plasticizer on the setting time of the compositions is given in Table 4. From the data obtained, adding the plasticizer can be seen to have slowed the setting of the compositions. In particular, the setting starts 1.5 hours later for the high-strength composition 
Table 3. The effect of the DC-5 plasticizer on the properties of the fluoroanhydrite composition

\begin{tabular}{|c|c|c|c|c|c|c|}
\hline \multirow{2}{*}{ Composition } & \multicolumn{2}{|c|}{ Strength after 28 days, $\mathrm{MPa}$} & \multirow{2}{*}{$\begin{array}{c}\text { Average density, } \\
\mathrm{kg} / \mathrm{m}^{3}\end{array}$} & \multirow{2}{*}{$\begin{array}{c}\text { Softening } \\
\mathrm{K}\end{array}$} & \multirow{2}{*}{$\begin{array}{c}\text { Water } \\
\text { absorption, \% }\end{array}$} & \multirow{2}{*}{$\begin{array}{l}\text { Coefficient of therma } \\
\text { conductivity, } \mathrm{W} / \mathrm{m}^{\circ} \mathrm{C}\end{array}$} \\
\hline & Tensile bending & Compressive & & & & \\
\hline 1 & 9.66 & 32.4 & 2023 & 0.71 & 5.6 & 0.715 \\
\hline 2 & 11.67 & 42.5 & 2193 & 0.91 & 1.9 & 0.721 \\
\hline 3 & 4.65 & 12.1 & 1344 & 0.52 & 20.4 & 0.380 \\
\hline 4 & 5.6 & 17.5 & 1594 & 0.67 & 10.6 & 0.473 \\
\hline
\end{tabular}

Table 4. The setting time of the compositions

\begin{tabular}{|c|c|c|}
\hline Composition & Start of setting & End of setting \\
\hline 1 & $2 \mathrm{~h} 13 \mathrm{~min}$ & $4 \mathrm{~h} 17 \mathrm{~min}$ \\
\hline 2 & $3 \mathrm{~h} 57 \mathrm{~min}$ & $4 \mathrm{~h} 48 \mathrm{~min}$ \\
\hline 3 & $5 \mathrm{~h} 19 \mathrm{~min}$ & $7 \mathrm{~h} 43 \mathrm{~min}$ \\
\hline 4 & $5 \mathrm{~h} 40 \mathrm{~min}$ & $7 \mathrm{~h} 58 \mathrm{~min}$ \\
\hline
\end{tabular}

and 20 minutes later for the composition lightened with expanded perlite sand compared to the control samples. The end of the setting occurs 30 (for high strength composition) and 15 minutes (for lightweight composition) later. Despite the reduction in setting speed, plasticized compositions comply with the technical requirements for the construction of self-leveling floor screeds.

\section{Physico-chemical studies of the structure of the composition}

Studies of the microstructure of the resulting composition were performed using a MIRA3 TESCAN microscope at the AdMaS Research Center of the Technical University of Brno. Figure 1 shows that the plasticized composition has a denser structure formed with the changing morphology of crystalline hydrate formations (Figure 1b) and the predominance of large blocks of monolithic gypsum crystals in it (Figure 1c).

In Figure $2 \mathrm{a}$, in the contact zone between the expanded perlite and the fluoroanhydrite matrix, the connection between them can be seen to be ensured by physical cohesion. In the plasticized composition (Figure $2 b, c$ ), perlite particles are coated with amorphous new formations.
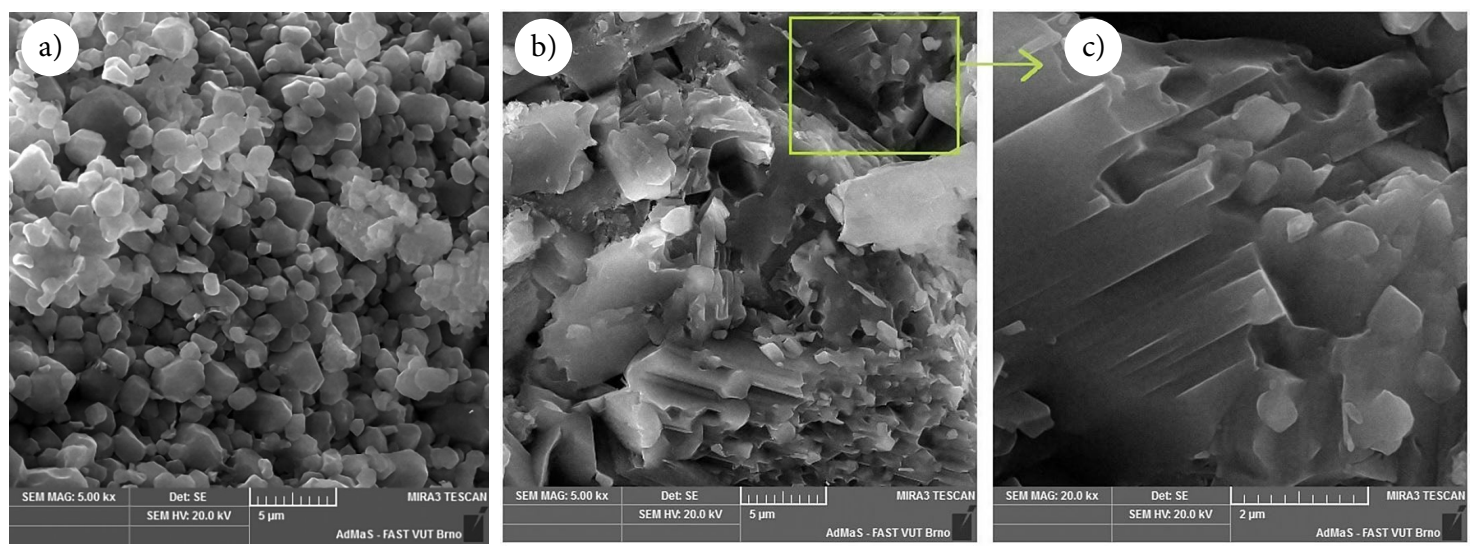

Figure 1. The microstructure of high strength fluoroanhydrite matrix: (a) - without plasticizer (5000-fold magnification), (b) - with the DC-5 plasticizer (5000-fold magnification), (c) - 20,000-fold microstructure fragment
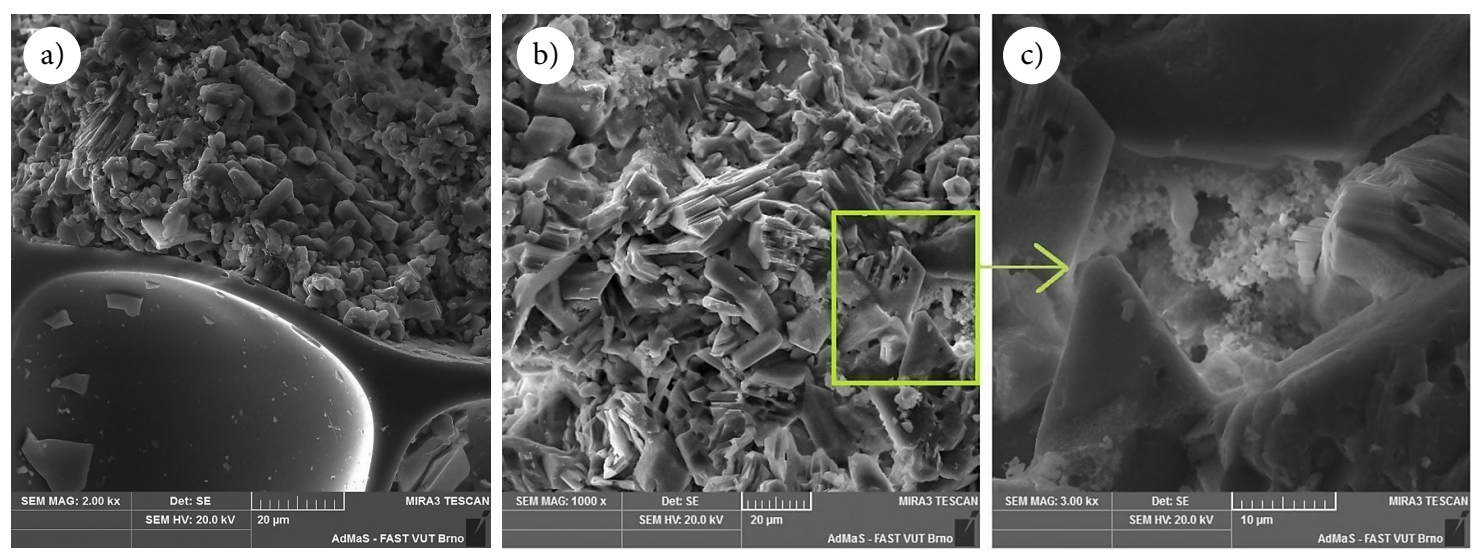

Figure 2. The microstructure of the composition with expanded perlite: (a) - in the contact zone without plasticizer,

(b) - with the DC-5 plasticizer, (c) - microstructure fragment with inclusion of perlite sand 

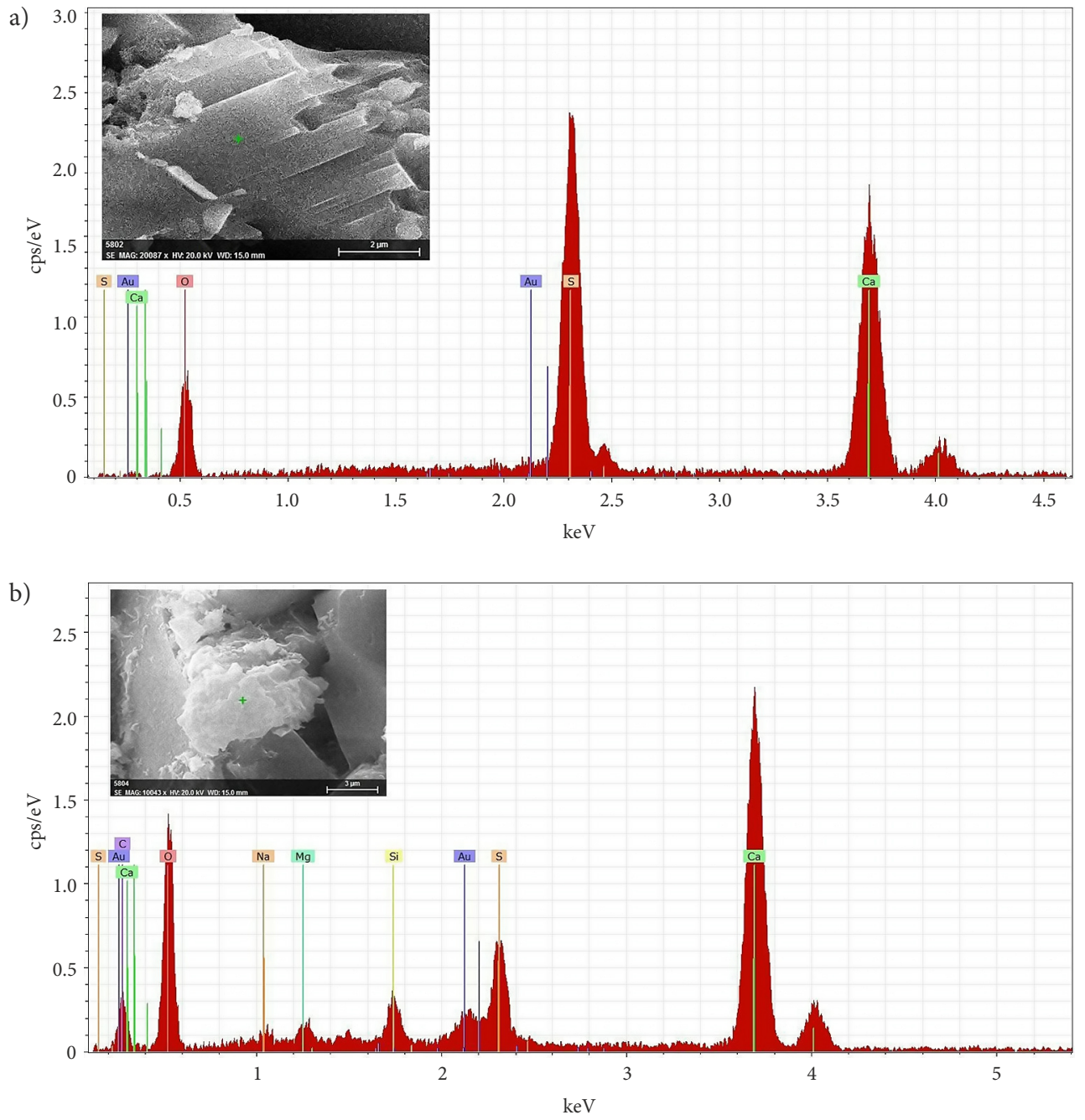

Figure 3. X-ray microanalysis of the microstructure of plasticized compositions: (a) - on the surface of crystalline hydrates, (b) - on the surface of amorphous structures

The chemical interaction that occurs at the interface between the fluoroanhydrite matrix and the surface of the expanded perlite sand in the plasticized composition leads to the appearance of amorphous new formations that improve the adhesion between crystalline hydrates in the hardened binder.

An X-ray microanalysis of the compositions made it possible to identify gypsum crystals (Figure 3a) as well as the presence of $\mathrm{Ca}, \mathrm{Si}$, and $\mathrm{O}$ atoms in amorphous new formations (Figure $3 \mathrm{~b}$ ), which suggests the formation of calcium hydrosilicates providing an additional increase in the strength of the composition.

\section{Conclusions}

Thus, adding a $2 \%$ aqueous solution of a plasticizer based on polycarboxylate esters modified with carbon nanotubes into the composition led to an increase in tensile bending strength by $20 \%$ and compressive strength by $46 \%$ compared to the control sample. Due to the compaction of the structure of the compositions, the water absorption of the material significantly reduced and the water resistance increased. The analysis of the microstructure of the composition confirmed the improved physical and mechanical characteristics due to a change in the morphology of crystalline hydrate formations with amorphous new formations appearing and an increase in the contact area between them. The developed compositions are suggested for self-leveling floors. The high-strength composition can be used either independently or as the top layer above the screed with reduced thermal conductivity made from the composition with expanded perlite sand.

\section{References}

Dolgorev, V. A., Dolgorev, A. V., \& Remnev V. V. (2008). Lightweight building mixes for floor insulation. In Materialy 4 Vserossiiskogo seminara s mezhdunarodnym uchastiem (pp. 60-64). Volgograd (in Russian).

Fedorchuk, Yu. M. (2013). Development of methods for involving sulfalcalcium waste of hydrogen production in the turn of the industrial use. Mezhdunarodnyi zhurnal prikladnykh $i$ fundamental'nykh issledovanii, 11(2), 151-155. https://applied-research.ru/ru/article/view?id=4476 
Goncharov, Yu. A., et al. (2016). Gypsum materials and products of a new generation. Energy efficiency rating. Colorgrad, Minsk (in Russian).

GOST 10832-2009. (2009). Pesok i shheben' perlitovye vspuchennye. Tehnicheskie uslovija [Expanded perlite sand and crushed stone. Technical specifications]. (GOST 10832-2009). Standartinform, Moskva. (in Russian).

Guan, B. H., Ye, Q. Q., Zhang, J. L., Lou, W. B., \& Wu, Z. B. (2010). Interaction between alphacalcium sulfate hemihydrate and superplasticizer from the point of adsorption characteristics, hydration and hardening process. Cement and Concrete Research, 40(2), 253-259.

https://doi.org/10.1016/j.cemconres.2009.08.027

Hampel, C., Zimmermann, J., \& Müller, M. (2013). Optimisation of plasticizers for gypsum applications. ZKG International, 66(2), 56-61.

Martin, D. (2015). Plasticizer composition for producing gypsum boards (EP3176141A1). European Patent Office.

Müller, M., \& Hampel, C. (2018). Multi-functional polymers for increased gypsum board production efficiency. 20th International Building Materials Conference "Ibausil", 2, 96-104.

Neuville, M., Bossis, G., Persello, J., Volkova, O., Boustingory P., \& Mosquet, M. (2012). Rheology of a gypsum suspension in the presence of different superplasticizers. Journal of Rheology, 56(2), 435-451. https://doi.org/10.1122/1.3693272

Pan, W., \& Wang, P. (2011). Effect of compounding of sodium tripolyphosphate and super plasticizers on the hydration of $\alpha$-calcium sulfate hemihydrate. Journal of Wuhan University of Technology-Mater. Sci. Ed., 26(4), 737-744. https://doi.org/10.1007/s11595-011-0303-4

Pureskina, O. A., Gashkova, V. I., Petrov, N. S., \& Katishev, S. F. (2010). The method of obtaining anhydrite binder (Patent RU 2382743). Ural'skij gosudarstvennyj tekhnicheskij universitetUPI imeni pervogo Prezidenta Rossii B.N. El'tsina (in Russian).

Sakthieswaran, N., \& Sophia, M. (2018). Effect of superplasticizers on the properties of latex modified gypsum plaster. Construction and Building Materials, 179, 675-691. https://doi.org/10.1016/j.conbuildmat.2018.05.150

Tan, H., Deng, X., Gu, B., Ma, B., Luo, S., Zhi, Z., Guo, Y., \& Zou, F. (2018). Effect of borax and sodium tripolyphosphate on fluidity of gypsum paste plasticized by polycarboxylate superplasticizer. Construction and Building Materials, 176, 394-402. https://doi.org/10.1016/j.conbuildmat.2018.05.005

TS 5744-132-05807960-98. (1998). Fluoroanhydrite (TS 5744132-05807960-98). Technical specifications (in Russian).

TS 2493-001-68708012-2014. (2014). Superplasticizer DC-5 (TS 2493-001-68708012-2014). Technical specifications. Kazan (in Russian).

Wang, Q., \& Jia, R. (2019). A novel gypsum-based self-leveling mortar produced by phosphorus building gypsum. Construction and Building Materials, 226, 11-20. https://doi.org/10.1016/j.conbuildmat.2019.07.289

Yakovlev, G. I., Pervushin, G. N., Grakhov, V. P., Kalabina, D. A., Gordina, A. F., Ginchitskaya, Y. N., Bazhenov, K. A., Troshkova, V. V., Drokhitka, R. V., \& Khozin, G. (2019a). Constructional and thermal insulation material based on high-strength anhydrite binder. Intellektual'nye sistemy $v$ proizvodstve, 17(1), 144-151. (in Russian).

https://doi.org/10.22213/2410-9304-2019-1-144-151
Yakovlev, G., Drochytka, R., Pervushin, G., Grahov, V., Kalabina, D., Gordina, A., \& Ginchitskaya, J. (2019b). Structural and thermal insulation materials based on high-strength anhydrite binder. IOP Conf. Series: Materials Science and Engineering, 603, 032071. https://doi.org/10.1088/1757-899X/603/3/032071

Yakovlev, G. I., Tulegenova, A. V., Pervushin, G. N., Keriene, J., Gordina, A. F., Bazhenov, K. A., \& Elrefaei, A. E. (2018). Multifunctional admixture used for activating fluoroanhydrite. 20th International Building Materials Conference "Ibausil", 2, 559-568. 